\title{
Catecholase-Like Activity and Theoretical Study in Solid State of a New Ru(III)-Schiff Base Complex
}

\author{
Niladri Biswas, ${ }^{1}$ Sandeepta Saha, ${ }^{1,2}$ Ennio Zangrando, ${ }^{3}$ Antonio Frontera ${ }^{4}$ \\ and Chirantan Roy Choudhury ${ }^{1, *}$ \\ ${ }^{1}$ Department of Chemistry, West Bengal State University, Barasat, Kolkata-700126, India \\ ${ }^{2}$ Sripur High School, Madhyamgram Bazar, Madhyamgram, Kolkata - 700130, India \\ ${ }^{3}$ Department of Chemical and Pharmaceutical Sciences, University of Trieste, Via L. Giorgieri 1, 34127 Trieste, Italy \\ ${ }^{4}$ Departament de Química, Universitat de les Illes Balears, Crta. De Valldemossa km 7.5, \\ 07122 Palma de Mallorca, Baleares, Spain \\ *Corresponding author: E-mail: crchoudhury2000@yahoo.com \\ Tel: + 91-9836306502; Fax: +91-33-2524-1577
}

Received: 09-13-2020

\begin{abstract}
A new ruthenium(III) complex of molecular formula $\left[\mathrm{Ru}\left(\mathrm{PPh}_{3}\right) \mathrm{Cl}_{2}(\mathrm{~L})\right]$ (1) has been synthesized using the Schiff base ligand obtained from 5-chlorosalicylaldehyde and $N, N$-dimethylethylenediamine and characterized by FT-IR, UV-Vis, cyclic voltammetry and single crystal X-ray structural analysis. The metal ion exhibits a slightly distorted octahedral environment where the chelating Schiff base ligand contributes with its NNO donor set. The coordination geometry around the $\mathrm{Ru}(\mathrm{III})$ ion is completed by a $\mathrm{PPh}_{3}$ ligand and two chloride anions, and the charge balance is assured by the phenoxo oxygen of the Schiff base. With the aim to analyse the energy related to the halogen bonding interactions in solid state, a theoretical study has been performed on complex 1, by using the MEP and NCl plot computational tools. Furthermore, complex 1 shows catecholase-like activity in conversion of the model substrate 3,5-di-tert-butylcatechol (3,5-DTBC) to the corresponding 3,5-di-tert-butylquinone (3,5-DTBQ) under aerobic condition. The parameters regarding the enzymatic kinetics have been evaluated from the Lineweaver-Burk plot using the Michaelis-Menten approach of enzyme catalysis. A significant high T.O.N value $\left(2.346 \times 10^{3} \mathrm{~h}^{-1}\right)$ indicates that complex 1 has a very good catalytic efficiency towards 3,5-DTBC.
\end{abstract}

Keywords: Ru-(III) complex $\cdot$ Schiff base $\cdot$ crystal structure $\cdot$ halogen interaction $\cdot$ catecholase-like activity

\section{Introduction}

In last decade, coordination chemistry of transition metal ions with Schiff bases has evolved as an an area of active research. ${ }^{1,2}$ Schiff bases affect electronic factors of the metal centres, stabilizing different oxidation states, address the performance of complexes, which can acquire a variety of suitable properties like that to act as homogeneous and/or heterogeneous catalysts. ${ }^{3-6}$ Moreover, design of metal complexes having catalytic activity may be helpful to elucidate the mechanistic aspects of biochemically important metalloenzyme reactions. In fact, structurally simpler and more robust metal complexes can mimic catalytic oxidation of 3,5-di-tert-butylcatechol to quinone, as well as hydrolytic reactions (catecholase and phosphatise activity, respectively). ${ }^{7}$ In the last decade a variety of ruthenium complexes, that provide great interest specially for their catalytic activity, has been developed. ${ }^{8-10}$
Ruthenium metal complexes may be also relevant as therapeutic agents and one of these has successfully entered advanced clinical trials. ${ }^{11}$ In fact the energy barrier for the oxidation state change from $\mathrm{Ru}(\mathrm{III})$ to $\mathrm{Ru}(\mathrm{II})$ inside the cell is very low and due to the larger coordination number with respect to platinum-(II), ruthenium-(III/II) can form complexes with a number of elements having different electronegativity as well as chemical hardness. ${ }^{1-14}$ Till date, there are plenty of reports on $\mathrm{Ru}(\mathrm{II} / \mathrm{III})$ compounds with bidentate ligands but design of such complexes with somewhat more rigid, tridentate Schiff bases ligands are rarely found. ${ }^{15}$

Intermolecular interactions, in addition to their structural role, influence the physical and chemical properties of crystalline solids. ${ }^{16,17}$ The advancement of these features has been one of the priorities of crystal engineering, a budding interdisciplinary field of research in modern 


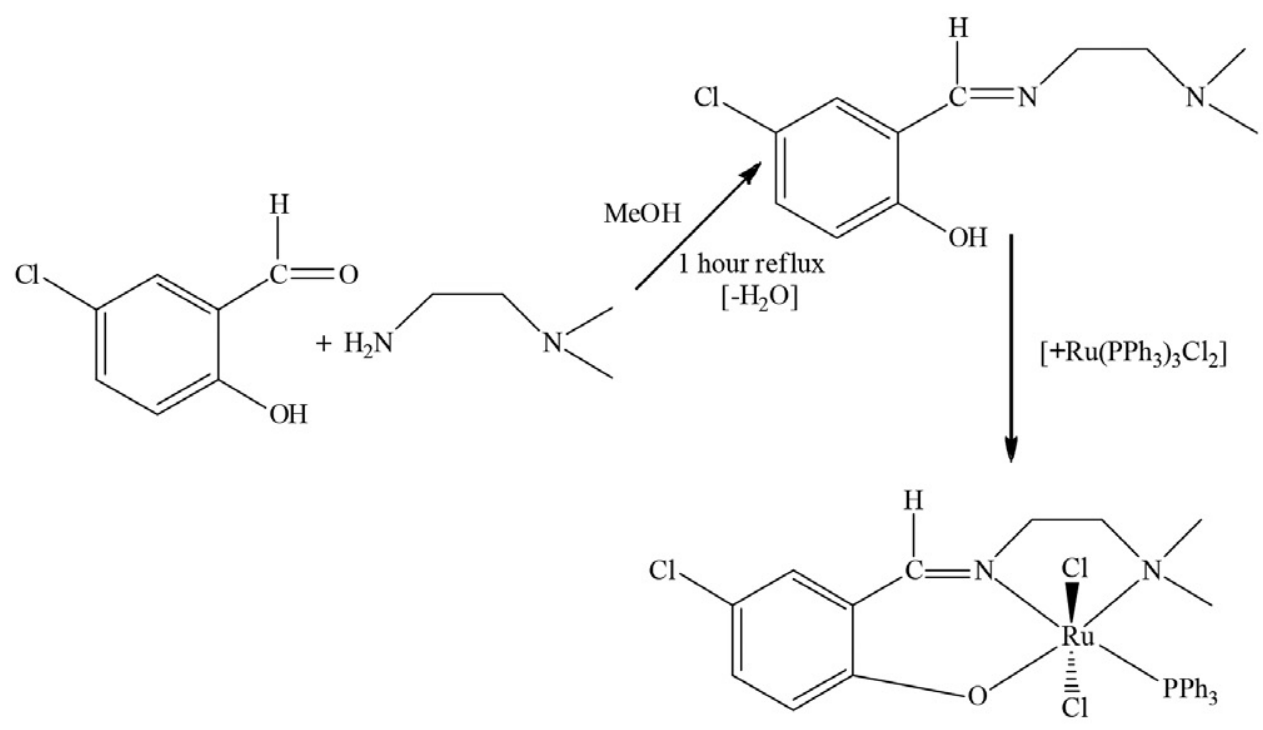

Scheme 1. Synthesis of the Schiff base ligand (HL) and complex 1.

chemistry with interest in the rational design of functional molecular solids. ${ }^{18}$ Even though hydrogen bonding and coordination bonds still remain at the forefront of crystal engineering strategies, Other interactions have received escalating interest over recent years, markedly, halogen bonds, ${ }^{19}$ non-classical hydrogen bonds, ${ }^{20} \pi-\pi$ interactions, ${ }^{21} l p-\pi$ interactions ${ }^{22}$ nitroso $\cdots$ nitroso interaction $s^{23}$ along with halogen $\cdots$ halogen contacts. ${ }^{20 \mathrm{~d}-\mathrm{f}}$ Intermolecular interactions involving halogen substituents, mostly chlorine, have been observed to favour crystal formation, providing a tool for crystal engineering study. ${ }^{24}$

Keeping this in mind, and taking into account that triphenylphosphine transition metal complexes are very good candidate for catalytic organic transformations, we report here the synthesis (Scheme 1) of a ruthenium(III) complex, $\left[\mathrm{Ru}\left(\mathrm{PPh}_{3}\right) \mathrm{Cl}_{2}(\mathrm{~L})\right]$ (1), which was characterized by different spectroscopic techniques, cyclic voltammetry. The single crystal X-ray structural analysis revealed interesting crystalline supra-molecular interactions. In addition, the complex has also been evaluated as model system for catecholase-like activity.

\section{Experimental Section}

\section{1. Materials}

All starting chemicals and solvents used in this study were of reagent grade and was used as purchased without further purification. Tris(triphenylphosphine)ruthenium(II) dichloride $\left[\mathrm{Ru}\left(\mathrm{PPh}_{3}\right)_{3} \mathrm{Cl}_{2}\right]$, 5-chlorosalicylaldehyde, 3,5-di-tert-butylcatechol (3,5-DTBC) and tetrabutylammonium perchlorate (TBAP) were purchased from Sigma-Aldrich, USA and N,N-dimethylethylenediamine from Spectrochem. Spectroscopic grade methanol and dimethyl sulfoxide (DMSO) were obtained from E-Merck, India.

\section{2. Physical Measurements}

FT-IR spectrum of complex 1 was measured in the range $400-4000 \mathrm{~cm}^{-1}$ in solid $\mathrm{KBr}$ pellets by using a Perkin-Elmer SPECTRUM-2 FT-IR spectrophotometer. The UV-Vis spectra were recorded using a Perkin-Elmer Lambda-35 UV-Vis spectrophotometer in Tris- $\mathrm{HCl}$ buffer medium at $300 \mathrm{~K}$. Elemental analyses were performed with a Perkin-Elmer 2400 II elemental analyzer. Electrochemical experiment was carried out with three electrode configuration using a CH 660E cyclic voltammeter in Tris$\mathrm{HCl}$ buffer medium. Saturated calomel electrode (SCE) as reference, $\mathrm{Pt}$ wire-electrode as counter electrode and glassy carbon electrode as working electrode were used as three electrode system with tetrabutylammonium perchlorate (TBAP) as supporting electrolyte at a scan rate of $50 \mathrm{mV} \mathrm{sec}{ }^{-1}$. Electrochemical data were recorded under a dry nitrogen environment. Nitrogen gas was passed into the sample solution at a constant rate for 1 minute.

\section{3. Synthetic Procedures}

\section{3. 1. Synthesis of Schiff Base Ligand (HL)}

The Schiff base ligand was prepared by the standard procedure mentioned in the literature. ${ }^{25 a-c} 5$-chlorosalicylaldehyde $(0.783 \mathrm{~g}, 5 \mathrm{mmol})$ in methanol medium was carefully added to a methanolic solution of N,N-dimethylethylenediamine $(0.538 \mathrm{~mL}, 5 \mathrm{mmol})$. The colour of the solution turned light yellow and the reaction mixture was allowed to reflux for one hour and then cooled at room temperature (Scheme 1). The synthesized Schiff base ligand was used for complex preparation without further purification.

\section{3. 2. Synthesis of Complex $\left[\mathrm{Ru}\left(\mathrm{PPh}_{3}\right) \mathrm{Cl}_{2}(\mathrm{~L})\right](1)$}

Solid $\left[\mathrm{Ru}\left(\mathrm{PPh}_{3}\right)_{3} \mathrm{Cl}_{2}\right](1.92 \mathrm{~g}, 2 \mathrm{mmol})$ was added to $30 \mathrm{~mL}$ methanolic solution of the Schiff base ligand (2 
mmol) followed by continuous stirring. After 6 hours of continuous reflux, shiny green coloured crystals were separated out (Scheme 1), collected by filtration, washed with diethyl ether and dried in vacuo. These crystals were used for the X-ray structural determination. Yield: $67 \%(0.256 \mathrm{~g})$.

Anal. Calc. Ffor $\left[\mathrm{C}_{29} \mathrm{H}_{29} \mathrm{C}_{13} \mathrm{~N}_{2} \mathrm{OPRu}\right]: \mathrm{C}, 52.73 ; \mathrm{H}$, 4.39 ; N, $4.24 \%$. Found: C, 52.65; H, 4.32; N, 4.18\%.

IR $\left(\mathrm{KBr} \mathrm{cm}^{-1}\right) 3436(\mathrm{~b}), 1631,696$ and 744 (s), 496, 481 and $1530(\mathrm{~m})$. Electronic spectrum in Tris- $\mathrm{HCl}$ buffer medium, $\lambda_{\max }(\mathrm{nm}): 260\left(\pi \rightarrow \pi^{*}\right), 360\left(\mathrm{n} \rightarrow \pi^{*}\right)$ and 683 $(\mathrm{d} \rightarrow \mathrm{d})$. ESI-MS: (m/z) [found (calcd)]: 661.0511 (659.93).

\section{4. Single Crystal X-ray Diffraction Study}

Data collection of complex 1 was performed at the X-ray diffraction beamline (XRD1) of the Elettra Synchrotron of Trieste (Italy), with a Pilatus2M image plate detector. Complete dataset was collected at $100 \mathrm{~K}$ with a monochromatic wavelength of $0.700 \AA$ with the rotating crystal method. The crystal was dipped in $\mathrm{N}$-paratone and mounted on the goniometer head with a nylon loop. The diffraction data were indexed, integrated and scaled using XDS. ${ }^{26}$ The structure was solved by direct methods ${ }^{27}$ and successive Fourier analysis and the refinement was performed by the full-matrix least-squares methods based on $F^{2}$ implemented in SHELXL-2014. ${ }^{27}$ Anisotropic thermal motion was allowed for all non-hydrogen atoms, and $\mathrm{H}$ atoms, at calculated positions, were included in the final cycles of refinement. All calculations were done with the Wingxpackage Version $2013.3{ }^{28}$ and the molecular graphics were prepared by using Cameron ${ }^{29}$ and DiamondVer $3.2 \mathrm{k}^{30}$ programs. Relevant crystallographic data and structure refinement parameters are summarized in Table T1 (Supplementary information).

\section{5. Theoretical Methods}

The geometry of the complex included in this study was computed at the M06-2X-D/def2-TZVP level of theory using the crystallographic coordinates. We have used the GAUSSIAN-09 program $^{31}$ was used for the calculations of the interaction energies and the molecular electrostatic potential (MEP) surfaces (at the same level of theory). We have also used the Grimme's dispersion ${ }^{32}$ correction being this adequate for the evaluation of noncovalent interactions. The NCI plot $^{33}$ isosurfaces have been used to characterize noncovalent interactions. These correspond to both favorable and unfavorable interactions, as differentiated by the sign of the second density Hessian eigen value and illustrated by the isosurface color. The color scheme is a red-yellow-green-blue scale, where red indicates $\rho^{+}$cut (repulsive) and blue for $\rho^{-}$cut (attractive). The Gaussian-09 M06-2X-D/def2-TZVP wave function has been used to generate the NCI plot.

\section{6. Catecholase Activity Study}

The catecholase-like activity of complex $\mathbf{1}$ has been investigated under aerobic condition at room temperature by using 3,5-di-tert-butylcatechol (3,5DTBC) as model substrate. Since complex $\mathbf{1}$ and the substrate are highly soluble in DMSO, the catalytic study was investigated in this particular solvent. The concentration of 3,5-DTBC was 100 times greater than that of the complex 1 . The process was followed spectrophotometrically at intervals of 10 mins. in the range of $200-600 \mathrm{~nm}$, and a significant increase of the 3,5-DTBQ concentration was observed by measuring its absorbance near $393 \mathrm{~nm}$. For each set of catalytic reaction, initial rates were calculated and the rate versus concentration of substrate was determined according to the Michaelis-Menten approach of enzymatic kinetics in order to get a Lineweaver-Burk plot. ${ }^{34-36}$ This methodology allowed to determine the $K_{\mathrm{m}}, V_{\max }$ and $k_{\text {cat }}$ values.

\section{Results and Discussion}

\section{1. Infrared Spectral Study}

IR spectrum of complex 1 (Fig. S1) showed a medium sharp band at $1631 \mathrm{~cm}^{-1}$, ascribed to the $v(\mathrm{C}=\mathrm{N})$ stretching, indicating the coordination of the azomethine nitrogen to the ruthenium(III) centre. ${ }^{37-39} \mathrm{~A}$ broad band found at $3436 \mathrm{~cm}^{-1}$ is due to the N-H stretching frequency. Well resolved bands, which appeared at 696, 744 and $1530 \mathrm{~cm}^{-1}$, are due to the stretching frequency of $\mathrm{PPh}_{3},{ }^{40,41}$ while $\mathrm{Ru}-\mathrm{N}$ and $\mathrm{Ru}-\mathrm{O}$ stretching frequencies appeared at 496 and $581 \mathrm{~cm}^{-1}$, respectively.

\section{2. Electronic Spectral Study}

The electronic spectrum of complex $\mathbf{1}$, recorded in Tris- $\mathrm{HCl}$ buffer medium, displayed three absorption bands in the UV-Vis region (Fig. S2). The high intensity band at $260 \mathrm{~nm}$, is assigned to intra ligand $\pi \rightarrow \pi^{*}$ transition of the imine in coordinated Schiff base, while the low intensity band at $360 \mathrm{~nm}$ can be attributed to $n \rightarrow \pi^{*}$ transition of the azomethine group. In addition, low energy band has been observed at $683 \mathrm{~nm}$, which can be assigned to $d \rightarrow d$ transition. In order to confirm the stability of complex $\mathbf{1}$, the UV-Vis spectral study was carried out for three successive days with same concentration of $\mathbf{1}$ in same medium, but no distinct change in the spectrum was observed.

\section{3. Cyclic Voltammetric Study}

The redox behaviour of complex 1 was studied by cyclic voltammetry by using a saturated calomel electrode (SCE) as reference. The ruthenium complex was found to be redox-active in the potential range from +2.0 to $-2.0 \mathrm{~V}$ (Fig. S3), and the redox potential was examined by well-defined waves at 0.37 and $0.72 \mathrm{~V}$ for the oxidation, and at -0.64 $\mathrm{V}$ for the reduction process. Of these, the peak at $+0.37 \mathrm{~V}$ ( $v s$. SCE) can be attributed to the $\mathrm{Ru}(\mathrm{III}) / \mathrm{Ru}(\mathrm{IV})$ oxidation, while that at $+0.72 \mathrm{~V}$ can be assigned to the Schiff base oxidation. The irreversible reduction peak at $-0.86 \mathrm{~V}$ ( $v s$. SCE) is associated to the $\mathrm{Ru}(\mathrm{III}) / \mathrm{Ru}(\mathrm{II})$ redox couple. 


\section{4. X-ray Crystal Structure Description}

The complex crystallizes in the monoclinic system, space group $P 2_{1} / \mathrm{c}$. The molecular structure of the complex is displayed in Fig. 1, while a packing diagram is shown in Fig. S5. (Supplementary information). All the relevant crystallographic data and structure refinement parameters for the complex reported are summarized in Table T1 (Supplementary information). A selection of bond distances and angles is collected in Table T2 (Supplementary information). The asymmetric unit consists of one complete complex molecule which is built by the tridentate Schiff base ligand meridionally coordinated, the triphenylphosphine molecule and two chlorides mutually located in trans position. The coordination geometry of the complex can be better described as distorted octahedral where the equatorial plane is formed by the donor atoms $\mathrm{O} 1, \mathrm{~N} 1$, and $\mathrm{N} 2$ donors of the chelating Schiff base (forming a six- and five-member ring) along with the $\mathrm{P}$ donor of the phosphine moiety. The coordination bond lengths $\mathrm{Ru}-\mathrm{O} 1, \mathrm{Ru}-\mathrm{N} 1$ and $\mathrm{Ru}-\mathrm{N} 2$ of the chelating ligand are 1.9757(13), 2.0384(15) and 2.2141(16) $\AA$, respectively, where the $\mathrm{Ru}-\mathrm{N}$ bond values differ due to the different hybridization of the $\mathrm{N}$ atoms $\left(s p^{2} v s . s p^{3}\right)$. Finally the coordination geometry is completed by the phosphine with $\mathrm{Ru}-\mathrm{P}$ distance is of 2.4058 (5) $\AA$ and two chlorides having comparable $\mathrm{Ru}-\mathrm{Cl}$ bond length of 2.3485(5) and 2.3569(5) $\AA$. Thus the +3 charge of the metal atom is satisfied by the chloride anions and the phenoxo oxygen (O1) of the Schiff base ligand. The distortion in the octahedron are well described by the bond angle values and the larger deviation from the ideal geometry is shown by the N2-Ru-P1 angle of $102.22(4)^{\circ}$, that appears induced by steric requirements. All the coordination distances (Table T2, Supplementary information) agree well with those reported for similar $\mathrm{Ru}(\mathrm{III})$ complexes. ${ }^{41-44}$

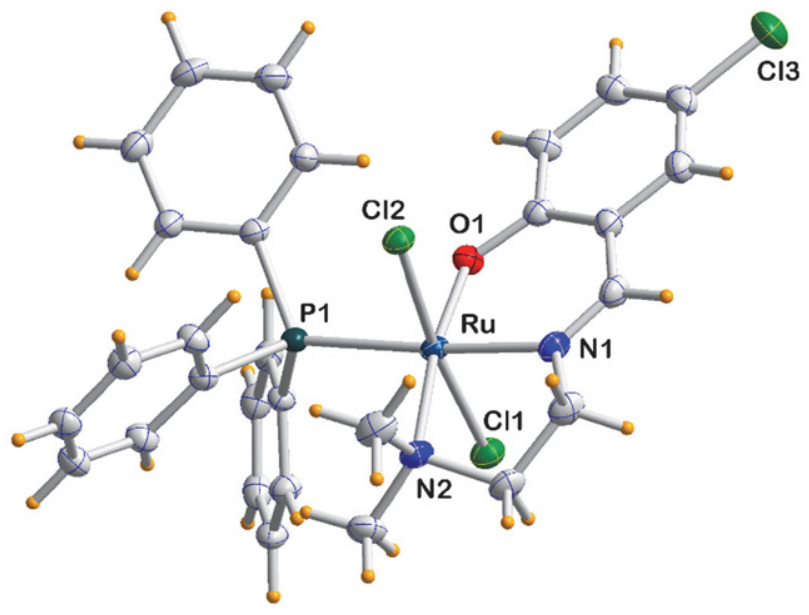

Fig. 1. ORTEP view of complex 1 with displacement ellipsoids drawn at $50 \%$ probability level (labels of $\mathrm{C}$ atoms not shown for clarity).

\section{5. Theoretical Study}

The crystal packing of 1 shows the complexes associated in pair through a symmetry center where $\mathrm{C}-\mathrm{Cl}$ bond of the aromatic ring points towards one chloride ligand of the symmetry related complex. This halogen-halogen like-interaction can be inferred taking into consideration the anisotropy of the charge density around the $\mathrm{Cl}$ atom. The theoretical study, using the MEP and NCI plot computational tools, is devoted to analyse the energy associated to this halogen interaction and to characterize it.

First the MEP surface of compound 1 was computed. It is worth mentioning that the more negative values of MEP are located at the chloro ligands $(-45 \mathrm{kcal} / \mathrm{mol})$. Since using the large scale given by the maximum and minimum MEP values the anisotropy around the chlo-

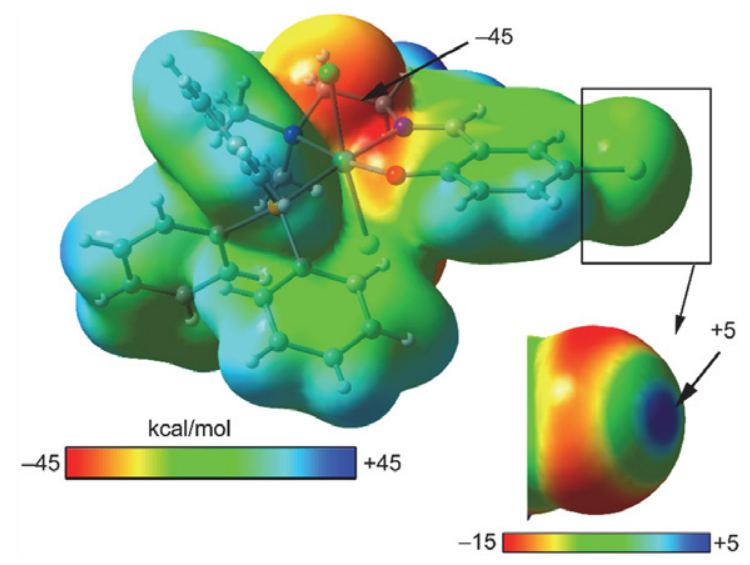

Fig. 2. MEP surface (isodensity $=0.002$ a.u.) of compound 1. The values are selected points of the surface are indicated. Negative values are in red and positive in blue colour.

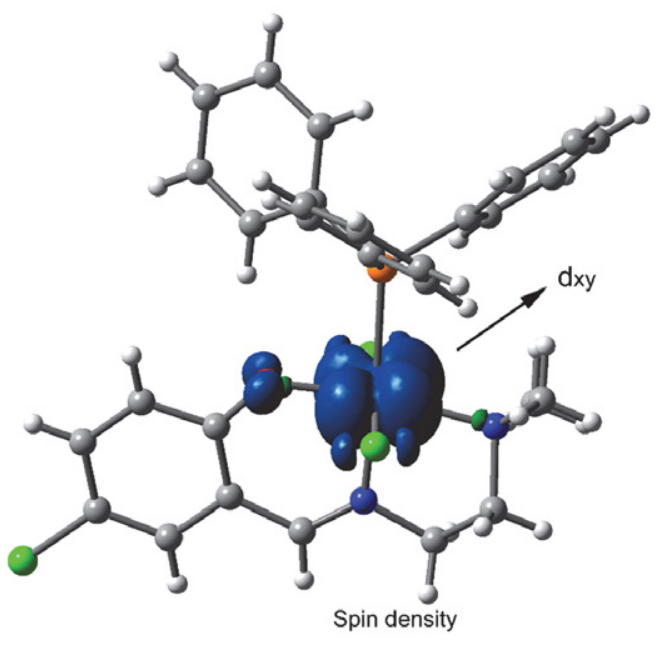

Fig. 3. Spin density plot of compound 1. Isodensity $=0.004$ a.u.

rine cannot be appreciated, so the MEP around this atom using a reduced scale is represented in Fig. 2. As a result, the $\sigma$-hole, of moderate energy $(+5 \mathrm{kcal} / \mathrm{mol})$, appears at the extension of the $\mathrm{C}-\mathrm{Cl}$ bond, while the typical negative 
belt around the $\mathrm{Cl}$ atom is larger in absolute value than the $\sigma$-hole $(-15 \mathrm{kcal} / \mathrm{mol})$. So, the MEP analysis confirms that the $\mathrm{Cl} \ldots \mathrm{Cl}$ like-like interactions are electrostatically favoured. The spin density plot (Fig. 3) of compound 1 was also computed in order to analyse the location of the unpaired electron that is located, as expected, at the $\mathrm{Ru}$ metal centre with some little delocalization onto the atoms directly bonded to it.

Fig. 4a shows a detail of the crystal packing of 1 with formation of the self-assembled dimer, where two symmetrically equivalent $\mathrm{Cl} \cdots \mathrm{Cl}$ interactions are established in addition to an antiparallel $\pi-\pi$ interaction. This arrangement also designates a double $\mathrm{Cl} \cdots \pi$ interaction, being the $\mathrm{Cl}$ located over one $\mathrm{C}$ atom of the aromatic ring at a distance $(3.63 \AA)$ slightly longer than the sum of the Van der Waals radii $\left(\sum \mathrm{r}_{\mathrm{vdW}}=3.45 \AA\right)$. It should be mentioned that the $\mathrm{Cl} \cdots \mathrm{Cl}$ distance is also slightly longer $(3.86 \AA)$ that the sum of Van der Waals radii $\left(\sum \mathrm{r}_{\mathrm{vdW}}=3.50 \AA\right)$. Therefore, by using DFT calculations, the dimerization energy of the pair of complexes were computed in solid state, and it was found to be moderately strong $\left(\Delta \mathrm{E}_{1}=-12.0 \mathrm{kcal} / \mathrm{mol}\right)$ and accounts for the $\pi-\pi, \mathrm{Cl} \cdots \mathrm{Cl}$ halogen and other long range Van der Waals interactions (Fig. 4b). In an attempt to evaluate the contribution of the halogen bonding interactions, an additional model was used where the chloro ligands have been replaced by two hydrides (indicated by small arrows in Fig. 4c). As a consequence, the reduced interaction energy $\left(\Delta \mathrm{E}_{2}=-11.1 \mathrm{kcal} / \mathrm{mol}\right)$ determines the contribution of the $\pi-\pi$ interaction and indicates that both the $\mathrm{Cl} \cdots \mathrm{Cl}$ interactions are very week $(-0.9 \mathrm{kcal} / \mathrm{mol})$, as

a)

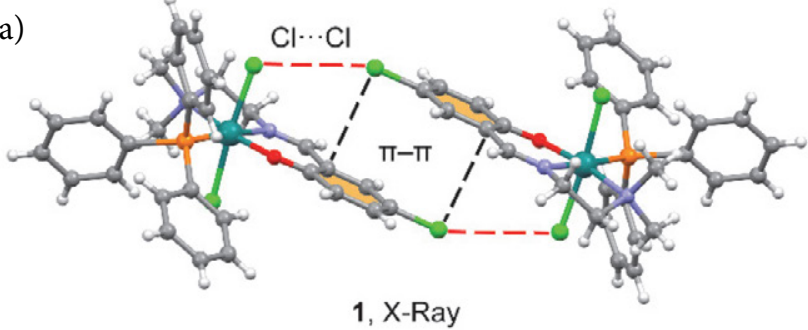

1, X-Ray

c)

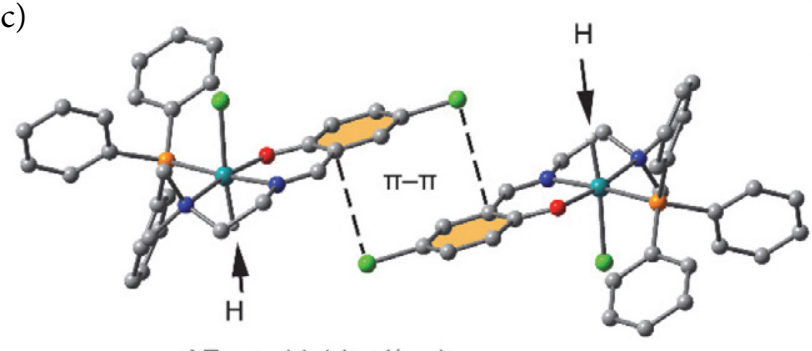

$\Delta \mathrm{E}_{2}=-11.1 \mathrm{kcal} / \mathrm{mol}$ expected taking into consideration the small MEP value observed at the $\sigma$-hole (Fig. 2). The "Non-Covalent Interaction (NCI) plot" was computed in order to characterize the interactions in the dimer of $\mathbf{1}$. The NCI plot is considered as an intuitive visualization index which enables the identification of non-covalent interactions easily and efficiently. In addition it is convenient for host-guest interaction analysis since it clearly shows the interacting molecular regions. Fig. $4 \mathrm{~d}$ shows the representation of the NCI plot, where the colour scheme is shown in red-yellow-green-blue scale: red means repulsive and blue stands for attractive interactions. Yellow and green surfaces correspond to weak repulsive or weak attractive interactions, respectively. As noted, the halogen bonds are characterized by the presence of a small green isosurface that is located between the $\mathrm{Cl}$ atoms, confirming the existence of the interaction. The NCI plot also shows the presence of a green and more extended isosurface between the $\pi$-systems of the ligands, indicating the existence of $\pi$-interactions that are also main contributor to the formation of the self-assembled dimer. Finally, the analysis reveals that the green isosurface extends in between the pair of the $\mathrm{Cl}$ atom and the aromatic-system, thus unequivocally confirms the existence of the $\mathrm{Cl} \cdots \pi$ interactions.

\section{6. Oxidation of 3,5-di-tert-butylcatechol (Kinetics Studies)}

The catalytic conversion of 3,5-DTBC to 3,5-DTBQ (Scheme 2) has already been investigated by a number of
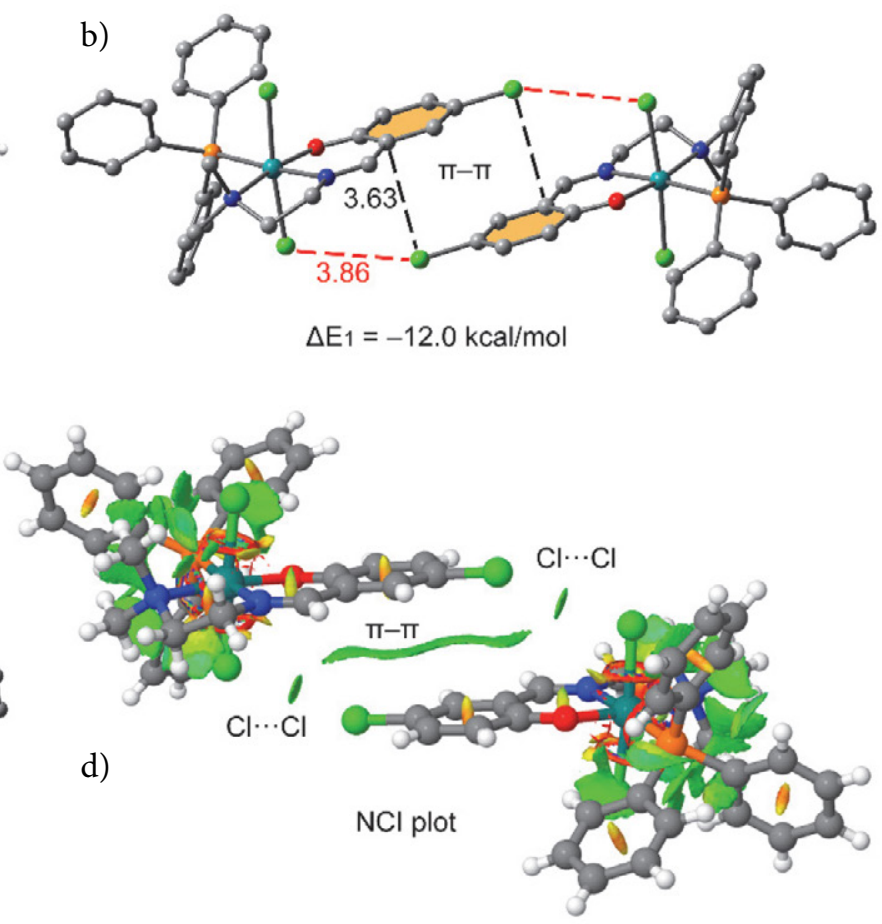

Fig. 4. (a) Detail of the crystal packing of 1. (b,c) Theoretical models used to evaluate the interaction energies. Distances in $\AA$. (d) NCI surface of the assembly present in compound $\mathbf{1}$. The gradient cut-off is $s=0.35$ a.u., and the color scale is $-0.04<\rho<0.04$ a.u. 
<smiles>CC(C)(C)C1=CC(=O)C(=O)C(C(C)(C)C)=C1</smiles>

Scheme 2. Oxidation process of 3,5-DTBC to 3,5-DTBQ.

scientist as a model catalytic reaction by using a variety of mono- ${ }^{45-60}$ di- ${ }^{31,51-63}$ tri/tetra- ${ }^{64-66}$ and poly-nuclear metal complexes. ${ }^{67} 3,5$-DTBC is the most widely used model substrate in catalytic oxidation process due to its low redox potential value that favours the oxidation to 3,5DTBQ, which shows absorbance maximum at $400 \mathrm{~nm}$ in DMSO.

It is evident that due to bulky substituent groups, no further ring opening oxidation reaction can take place. ${ }^{68}$ The exceptionally high stability of 3,5-DTBQ is indicative of a single reaction pathway and the formed benzoquinone does not undergo further oxidative cleavage.

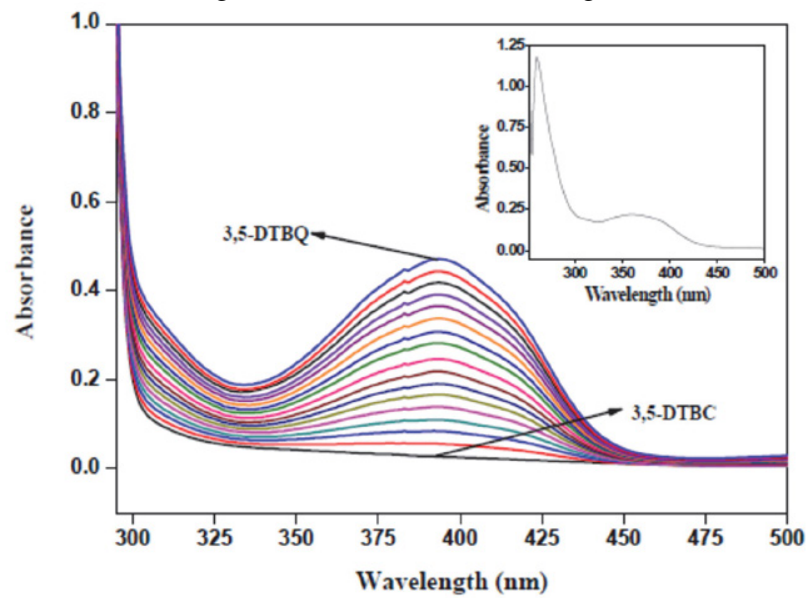

Fig. 5. Increase of the 3,5-DTBQ absorbance band at $393 \mathrm{~nm}$ after addition of $1 \times 10^{-4} \mathrm{M}$ DMSO solution of complex 1 to 100 equivalents of 3,5-DTBC at various intervals from 10 to 160 mins. Inset shows the UV-Vis spectrum of $\mathbf{1}$ in DMSO at room temperature.

However, before investigating a detailed catalytic study, it was important to verify the ability of complex 1 to oxidise 3,5-DTBC. For this reason, a DMSO solution 1 $\times 10^{-4} \mathrm{M}$ of complex 1 was treated with 100 equivalents of 3,5-DTBC following the reaction by UV-Vis spectroscopy over the first 160 mins. After addition of 3,5-DTBC to the solution of $\mathbf{1}$, the time dependent spectral scans display a smooth increase of the quinone band at $393 \mathrm{~nm}$, indicating a significant catalytic activity of the complex as shown in Fig. 5. Thus the kinetics of the oxidation of 3,5-DTBC to 3,5-DTBQ was investigated by the method of initial rates by monitoring the growth of quinone band at $393 \mathrm{~nm}$ as a function of time. A graph of the absorbance difference $(\triangle \mathrm{A})$ of 1 at $393 \mathrm{~nm}$ in presence of 3,5-DTBC was plotted

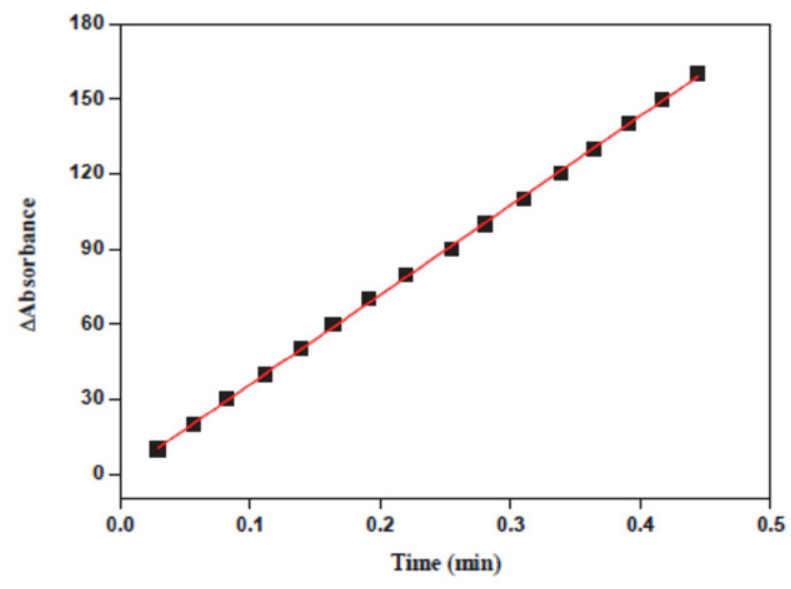

Fig. 6. Plot of absorbance difference $(\Delta \mathrm{A}) v$ s. time to determine the initial rate of the catalytic oxidation of 3,5-DTBC by complex $\mathbf{1}$ in DMSO.

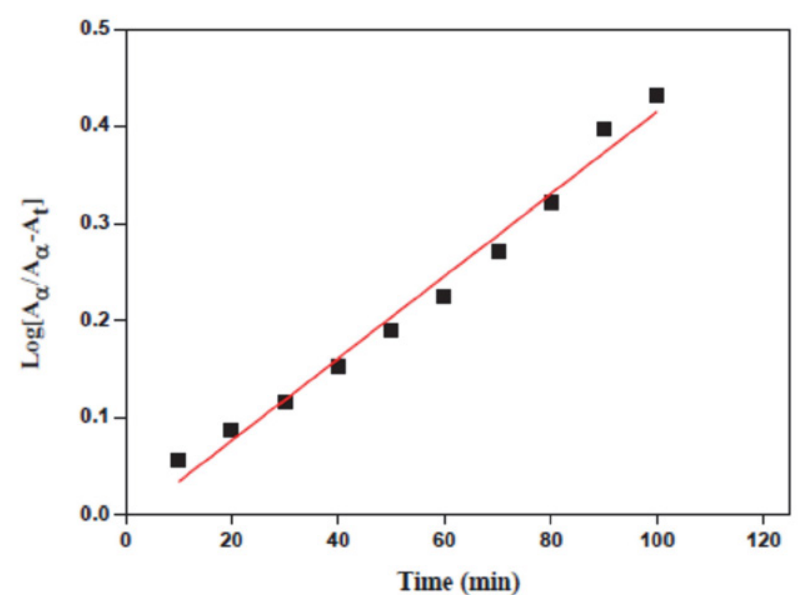

Fig. 7. Change in absorption maxima at $393 \mathrm{~nm}$ with time after incremental addition of DMSO solution $1 \times 10^{-4} \mathrm{M}$ of complex 1 to 100 equivalents of 3,5 -DTBC.

against time to determine the rate/velocity for the catalyst to substrate concentration ratio (Fig. 6). The rate constant was determined from the slope of the plot $\log \left[\mathrm{A}_{\alpha} /\left(\mathrm{A}_{\alpha}-\mathrm{A}_{t}\right)\right]$ $v s$. time $(\mathrm{t})$ (where $\mathrm{A}_{\alpha}$ and $\mathrm{A}_{\mathrm{t}}$ are the absorbance at infinite and ' $t$ ' time, respectively). The obtained straight line (Fig. 7) passes through the origin with a slope of $5.28 \times 10^{-3}$.

The rate constant $v s$. substrate concentration plot was well explained on the basis of Michaelis-Menten approach of enzymatic kinetics and its graphical representation was done in the form of the Lineweaver-Burk plot allowed to determine the kinetic parameters. The Michaelis binding constant $\left(K_{\mathrm{M}}\right)$, maximum velocity $\left(V_{\max }\right)$, rate constant for the dissociation of the substrate (i.e., turnover number, $k_{\text {cat }}$ ) for complex 1 were calculated from the LineweaverBurk plot of $1 / \mathrm{V}$ vs. 1/[S] (Fig. 8) using the equation $1 / \mathrm{V}$ $=\left\{K_{\mathrm{m}} / V_{\max }\right\}\{1 /[\mathrm{S}]\}+1 / V_{\max }$. For the complex, a first-order catalytic reaction was detected at low concentration of the substrate 3,5-DTBC, while saturation kinetics was observed at higher concentration (shown in Fig. 8). At ex- 


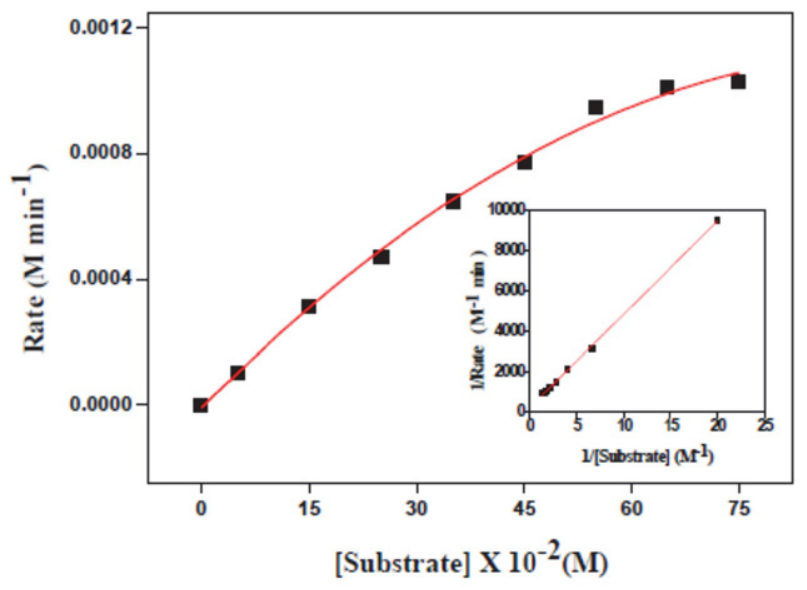

Fig. 8. Plot of initial rate versus substrate concentration [3,5-DTBC] for the catalytic oxidation reaction by complex 1 . The inset shows the Lineweaver -Burk plot.

cess substrate condition, the Michaelis-Menten approach of enzymatic kinetics is the best appropriate method. ${ }^{46}$ The $k_{\text {cat }}$ value was calculated by dividing $V_{\max }$ value by the concentration of complex 1 . The kinetic parameters for the catalytic oxidation of 3,5-DTBC mediated by complex 1 were determined as follows: $V_{\max }=9.31 \times 10^{-3} \mathrm{M} \mathrm{min}^{-1}$, $K_{\mathrm{M}}=1.805 \mathrm{M}$, T.O.N $\left(K_{\text {cat }}\right)=2.346 \times 10^{3} \mathrm{~h}^{-1}$, efficiency $\left(K_{\text {cat }} / K_{\mathrm{M}}\right)=21.66 \mathrm{M}^{-1} \mathrm{~min}^{-1}$. Manganese(II/III), nickel(II), copper(II), zinc(II) and cobalt(II/III) complexes have been used as prominent catalysts for catechol oxidation. Previous studied revealed that the oxidation occurs with catalyst only and not with impurities. ${ }^{69}$ In Table 1 the $k_{\text {cat }}$ value of complex 1 in DMSO, of $2.346 \times 10^{3} \mathrm{~h}^{-1}$, is compared with that of related reported metal complexes. It is worth

Table 1. Representative examples of metal catalysts for catechol oxidase activity having comparable TON value to $\mathbf{1}$ along with their turnover numbers.

Complexes having comparable T.O.N value to 1 .

\begin{tabular}{lll}
\hline Complexes & $\begin{array}{l}\text { T.O.N } \times \mathbf{1 0}^{\mathbf{3}} \\
\left(\boldsymbol{K}_{\text {cat }}\right)\left(\mathbf{h}^{-\mathbf{1}}\right)\end{array}$ & References \\
\hline 1. $\left[\mathrm{Co}(\mathrm{L})_{2}\left(\mathrm{ClO}_{4}\right)_{3}\right]$ & 5.02 & 58 \\
2. $\left[\mathrm{Cu}_{2}\left(\mathrm{Sbal}_{2}\left(\mathrm{H}_{2} \mathrm{O}\right)_{2}\right]\right.$ & 1.287 & 36 \\
3. $\left[\mathrm{Cu}_{2}\left(\mathrm{Sab}_{4}\right)_{2}\left(\mathrm{H}_{2} \mathrm{O}\right)_{2}\right] \cdot 0.5 \mathrm{H}_{2} \mathrm{O}$ & 3.8 & 36 \\
4. $\left[\mathrm{Co}(\mathrm{L})_{3}\right]=\mathrm{C}_{42} \mathrm{H}_{39} \mathrm{~N}_{6} \mathrm{O}_{3} \mathrm{~S}_{3} \mathrm{Co}$ & 3.47 & 56 \\
5. $\left[\mathrm{Ni}_{(}(\mathrm{L})_{2}\right]=\mathrm{C}_{28} \mathrm{H}_{26} \mathrm{~N}_{4} \mathrm{O}_{2} \mathrm{~S}_{2} \mathrm{Ni}$ & 2.68 & 56 \\
6. $\left[\mathrm{Cu}_{2}\left(\mathrm{Ala}_{5} \mathrm{OMe}\right)_{2}\right]$ & 2.580 & 63 \\
7. $\left[\mathrm{Cu}_{2}\left(\mathrm{Ala}_{5} \mathrm{Cl}\right)_{2}\right]$ & 1.410 & 63 \\
8. $\left[\mathrm{Cu}_{2}\left(\mathrm{Ala}_{5} \mathrm{Br}\right)_{2}\right]$ & 1.80 & 63 \\
9. $\left[\mathrm{Cu}_{2}\left(\mathrm{Val}_{5} \mathrm{Br}\right)_{2}\left(\mathrm{H}_{2} \mathrm{O}\right)\right] \cdot 0.5 \mathrm{H}_{2} \mathrm{O}$ & 2.760 & 63 \\
10. $\left[\mathrm{Cu}_{2}\left(\mathrm{Leu}_{5} \mathrm{Br}\right) 2\right] \cdot 0.2 \mathrm{H}_{2} \mathrm{O}$ & 3.960 & 63 \\
11. $\mathrm{Ni}\left(\mathrm{L}^{1}\right) \mathrm{ClO}_{4}$ & 8.0 & 55 \\
12. $\mathrm{Ni}\left(\mathrm{L}^{2}\right) \mathrm{ClO}_{4}$ & 2.7 & 55 \\
13. $\left[\mathrm{Ru}\left(\mathrm{PPh}_{3}\right) \mathrm{Cl}_{2}(\mathrm{~L})\right]$ & 2.346 & this paper \\
\hline
\end{tabular}

of note that complex 1 exhibits a moderate turnover number among the other $\mathrm{Ru}(\mathrm{III})$ metal complexes (Table T3, Supplementary information).

It can be concluded that the $\mathrm{Ru}(\mathrm{III})$ catalyst reported in this work appears an efficient synthetic complex for the catecholase reaction and can also be considered as a functional model for this process.

\section{Conclusion}

The following are the salient observations and findings of the present work:

(a) At our knowledge this is the first $\mathrm{Ru}(\mathrm{III})$ complex structurally characterized of $\mathrm{Ru}(\mathrm{III})$ with the Schiff base ligand derived from 5-chlorosalicylaldehyde and $\mathrm{N}, \mathrm{N}$-dimethylethylenediamine (HL).

(b) The complex $\left[\mathrm{Ru}\left(\mathrm{PPh}_{3}\right) \mathrm{Cl}_{2}(\mathrm{~L})\right]$ was characterized by elemental analysis and available spectroscopic IR, UVVis techniques, along with single crystal X-ray analysis.

(c) The crystal packing of the present compound exhibits halogen bonding interactions in solid state. The energies associated to these interactions have been evaluated using DFT calculations, and further corroborated with NCI plot index computational tool.

(d) The complex shows promising catalytic activity in the conversion of 3,5-DTBC to 3,5-DTBQ, and its T.O.N value is significantly higher in comparison with other $\mathrm{Ru}$ complexes.

\section{Conflict of interest}

There are no conflicts of interest to declare.

\section{Acknowledgements}

S. Saha, N. Biswas, C. Roy Choudhury are grateful to Late Prof. Samiran Mitra, Department of Chemistry, Jadavpur University, for his work about this manuscript. S. Saha gratefully acknowledges UGC for awarding Senior Research Fellowship (SRF). N. Biswas acknowledges CSIR, New Delhi, Govt. of India, for awarding junior research fellowship (Project No: 01/2537/11- EMR - II). C. Roy Choudhury acknowledges DST- FIST (Project No. SR/ FST/CSI-246/2012) New Delhi, Govt. of India for instrumental support under capital heads.

\section{Appendix A. Supplementary data}

CCDC 1854395 contains the supplementary crystallographic data for complex $\mathbf{1}$. These data can be obtained free of charge via http://www.ccdc.cam.ac.uk/conts/retrieving.html, or from the Cambridge Crystallographic Data Centre, 12 Union Road, Cambridge CB2 1EZ, UK; 
fax: (+44) 1223-336-033; or e-mail: deposit@ccdc.cam. ac.uk. Supplementary data associated with this article can be found, in the online version, at http://

\section{References}

1. K. C. Gupta, A. K. Sutar, Coord. Chem. Rev. 2008, 252, 14201450. DOI:10.1016/j.ccr.2007.09.005

2. E. Ritter, P. Przybylski, B. Brzezinski, F. Bartl, Curr. Org. Chem. 2009, 13, 241-249. DOI:10.2174/138527209787314805

3. I. P. Ejidike, P. A. Ajibade, Bioinorg. Chem. Appl. 2016, 2016, 1-11. DOI:10.1155/2016/9672451

4. T. Opstal, F. Verpoort, Angew. Chem. Int. Ed., 2003, 42, 28762879. DOI:10.1002/anie.200250840

5. B. De Clercq, F. Lefebvre, F. Verpoort, Appl. Catal. A Gen. 2003, 247, 345-364. DOI:10.1016/S0926-860X(03)00126-1

6. A. Gölcü, M. Tümer, H. Demirelli, R. A. Wheatley, Inorg. Chim. Acta 2005, 358, 1785-1797. DOI:10.1016/j.ica.2004.11.026

7. A. Neves, L. M. Rossi, A. J. Bortoluzzi, B. Szpoganicz, C. Wiezbicki, E. Schwingel, W. Haase, S. Ostrovsky, Inorg. Chem. 2002, 41, 1788-1794. DOI:10.1021/ic010708u

8. A. F. Shoair, A. R. El-Shobaky, E. A. Azab, Spectrochim. Acta. Part A: Mol. Biomol. Spectrosc. 2015, 151, 322-334.

DOI:10.1016/j.saa.2015.06.011

9. Y. Yamamoto, K. Fukatsu, H. Nishiyama, Chem. Commun. 2012, 48, 7985-7987. DOI:10.1039/c2cc34044e

10. P. Barbaro, C. Bianchini, A. Meli, M. Moreno, F. Vizza, Organometallics 2002, 21, 1430-1437. DOI:10.1021/om011005n

11. I. Bratsos, S. Jedner, T. Gianferrara, E. Alessio, CHIMIA Int J Chem. 2007, 61, 692-697. DOI:10.2533/chimia.2007.692

12. A. A. A. Aziz, H. A. Elbadawy, Spectrochim. Acta. Part A: Mol. Biomol. Spectrosc. 2014, 124, 404-415.

DOI:10.1016/j.saa.2014.01.050

13. P. Schluga, C. G. Hartinger, A. Egger, E. Reisner, M. Galanski, M. A. Jakupec, B. K. Keppler, Dalton Trans. 2006, 2006, 1796-1802. DOI:10.1039/b511792e

14. V. Brabec, Nucleic Acid Res. Mol. Biol. 2002, 71, 1-68. DOI:10.1016/S0079-6603(02)71040-4

15. A. Garza-Ortiz, P. U. Maheswari, M. Siegler, A. L. Spek, J. Reedijk, New J. Chem. 2013, 37, 3450-3460.

DOI:10.1039/c3nj00415e

16. H. M. Yamamoto, J. Yamaura, R. Kato, J. Am. Chem. Soc. 1998, 120, 5905-5913.

DOI:10.1021/ja980024u and references therein.

17. (a) L. Brammer, Chem. Soc. Rev. 2004, 33, 476-489. DOI: $10.1039 / \mathrm{b} 313412 \mathrm{c}$

(b) A. Matsumoto, T. Tanaka, T. Tsubouchi, K. Tashiro, S. Saragai, S. Nakamoto, J. Am. Chem. Soc. 2002, 124, 8891-8902. DOI:10.1021/ja0205333

(c) L. R. MacGillivray, J. L. Reid, J. A. Ripmeester, J. Am. Chem. Soc. 2000, 122, 7817-7818. DOI:10.1021/ja001239i

(d) L. R. MacGillivray, Cryst. Eng. Comm. 2002, 4, 37-41.

DOI:10.1039/b200332e

(e) M. Fourmigué, Recent advances Curr. Opin. Solid State Mater Sci. 2009, 13, 36-45. DOI:10.1016/j.cossms.2009.05.001
18. G. R. Desiraju, Crystal Engineering. The Design of Organic Solids, Elsevier, Amsterdam, 1989.

19. (a) L. Brammer, G. Mínguez Espallargas, S. Libri, Cryst. Eng. Comm. 2008, 10, 1712-1727. DOI:10.1039/b812927d

(b) P. Metrangolo, T. Pilati, G. Resnati, Cryst. Eng. Comm. 2006, 8, 946-947. DOI:10.1039/b610454a

(c) K. Rissanen, Cryst. Eng. Comm. 2008, 10, 1107-1113.

DOI:10.1039/b803329n

(d) S. Samai, K. Biradha, Cryst. Eng. Comm. 2009, 11, 482492. DOI:10.1039/B813263A

e) P. Metrangolo, T. Pilati, G. Terraneo, S. Biella, G. Resnati, Cryst. Eng. Comm. 2009, 11, 1187-1196.

DOI: $10.1039 / \mathrm{b} 821300 \mathrm{c}$

(f) G. R. Desiraju, P. S. Ho, L. Kloo, A. C. Legon, R. Marquardt, P. Metrangolo, P. Politzer, G. Resnati, K. Rissanen, Pure Appl. Chem. 2013, 85, 1711-1713.

DOI:10.1351/PAC-REC-12-05-10

20. (a) D. Braga, F. Grepioni, New J. Chem. 1998, 22, 1159-1161. DOI:10.1039/a806554c

(b) G. R. Desiraju, T. Steiner, The Weak Hydrogen Bond in Structural Chemistry and Biology, Oxford University Press, New York, 1990

(c) P. J. Langley, J. Hulliger, R. Thaimattamand, G. R. Desiraju, New J. Chem. 1998, 22, 1307-1309. DOI:10.1039/a807552b (d) G. R. Desiraju, R. Parthasarathy, J. Am. Chem. Soc. 1989, 111, 8725-8726. DOI:10.1021/ja00205a027

(e) A. R. Jagarlapudi, P. Sarma, G. R. Desiraju, Acc. Chem. Res. 1986, 19, 222-228. DOI:10.1021/ar00127a005

(f) C. M. Reddy, M. T. Kirchner, R. V. Gundakaram, K. A. Padmanabhan, G. R. Desiraju, Chem. Eur. J. 2006, 12, 2222 2234. DOI:10.1002/chem.200500983

21. (a) S. Saha, N. Biswas, A. Sasmal, C.J. Gómez-García, E. Garribba, A. Bauza, A. Frontera, G. Pilet, G. Rosair, S. Mitra, C. Roy Choudhury, Dalton Trans. 2018, 47, 16102-16118.

DOI:10.1039/C8DT02417K

(b) S. Saha, A. Sasmal, C. Roy Choudhury, G. Pilet, S. Mitra, Inorg. Chim. Acta 2015, 425, 211-220.

DOI:10.1016/j.ica.2014.10.007

22. S. Saha, C. Roy Choudhury, C. J. Gómez-García, E.Garribba, A. Bauzá, A. Frontera, G. Pilet, S. Mitra, Inorg. Chim. Acta 2017, 461, 183-191. DOI:10.1016/j.ica.2017.02.016

23. S. Saha, A. Sasmal, G. Pilet, A. Bauzá, A. Frontera, S. Mitra, Cryst. Eng. Comm. 2014, 16, 654-666.

\section{DOI:10.1039/C3CE41765D}

24. P. Metrangolo, F. Meyer, T. Pilati, G. Resnati, G. Terraneo, Angew. Chem. Int. Ed. 2008, 47, 6114-6127.

DOI:10.1002/anie.200800128 and references therein.

25. (a) S. Y. Liu, H. N. Hu, Y. P. Ma, Synth. React. Inorg. Met-Org. Nano-Metal Chem.2013, 43, 734-738.

DOI:1080/15533174.2012.754764

(b) Z. L. You, Q. Z. Jiao, S. Y. Niu, J. Y. Chi, Z.Anorg. Allgem. Chem. 2006, 632, 2481-2485. DOI:10.1002/zaac. 200600198 (c) A. Bhattacharjee, S. Halder, K. Ghosh, C. Rizzoli, P. Roy, New J. Chem. 2017, 41, 5696-5706.

DOI:10.1039/C7NJ00846E

26. W. Kabsch, Acta Cryst. 2010, D66, 125-132. 
DOI:10.1107/S0907444909047337

27. G. M. Sheldrick, Acta Cryst. 2008, A64, 112-122. DOI: $10.1107 /$ S0108767307043930

28. L .J. Farrugia, J. Appl. Cryst. 2012, 45, 849-854. DOI:10.1107/S0021889812029111

29. D. J. Watkin, C. K. Prout, L. J. Pearce, 1996, CAMERON. Chemical Crystallography Laboratory, Oxford, England.

30. K. Brandenburg, 1999, DIAMOND. Crystal Impact GbR, Bonn, Germany.

31. M. J. Frisch, G. W. Trucks, H. B. Schlegel, G. E. Scuseria, M. A. Robb, J. R. Cheeseman, G. Scalmani, V. Barone, B. Mennucci, G. A. Petersson, H. Nakatsuji, M. Caricato, X. Li, H. P. Hratchian, A. F. Izmaylov, J. Bloino, G. Zheng, J. L. Sonnenberg, M. Hada, M. Ehara, K. Toyota, R. Fukuda, J. Hasegawa, M. Ishida, T. Nakajima, Y. Honda, O. Kitao, H. Nakai, T. Vreven, J. A. Montgomery, Jr., J. E. Peralta, F. Ogliaro, M. Bearpark, J. J. Heyd, E. Brothers, K. N. Kudin, V. N. Staroverov, R. Kobayashi, J. Normand, K. Raghavachari, A. Rendell, J. C. Burant, S. S. Iyengar, J. Tomasi, M. Cossi, N. Rega, J. M. Millam, M. Klene, J. E. Knox, J. B. Cross, V. Bakken, C. Adamo, J. Jaramillo, R. Gomperts, R. E. Stratmann, O. Yazyev, A. J. Austin, R. Cammi, C. Pomelli, J. W. Ochterski, R. L. Martin, K. Morokuma, V. G. Zakrzewski, G. A. Voth, P. Salvador, J. J. Dannenberg, S. Dapprich, A. D. Daniels, Ö. Farkas, J. B. Foresman, J. V. Ortiz, J. Cioslowski, D. J. Fox, Gaussian 09 Gaussian, Inc., Wallingford CT, 2009.

32. S. Grimme, J. Antony, S. Ehrlich, H. Krieg, J. Chem. Phys. 2010, 132, 154104-154119. DOI:10.1063/1.3382344

33. J. Contreras-García, E. R. Johnson, S. Keinan, R. Chaudret, J. P. Piquemal, D. N. Beratan, W. Yang, J. Chem. Theory Comput. 2011, 7, 625-632. DOI:10.1021/ct100641a

34. K. Ghosh, A. Banerjee, A. Bauza, A. Frontera, S. Chattopadhyay, RSC Adv. 2018, 8, 28216-28137.

DOI:10.1039/C8RA03035A

35. C. Gerdemann, C.Eicken, B. Krebs, Acc. Chem. Res. 2002, 35, 183-191. DOI:10.1021/ar990019a

36. C. T. Yang, M. Vetrichelvan, X. Yang, B. Moubaraki, K. S. Murray, J. J. Vittal. Dalton Trans. 2004, 113-121.

DOI:10.1039/B310262A

37. P. Kalaivani, R. Prabhakaran, E. Vaishnavi, T. Rueffer, H. Lang, P. Poornima, R. Renganathan, V. VijayaPadma, K. Natarajan, Inorg. Chem. Front. 2014, 1, 311-324.

DOI:10.1039/c3qi00070b

38. R. Prabhakaran, C. Jayabalakrishnan, V. Krishnan, K. Pasumpon, D. Sukanya, H. Bertagnolli, K. Natarajan, Appl.Organomet. Chem. 2006, 20, 203-213. DOI:10.1002/aoc.1026

39. R. Prabhakaran, R. Karvembu, T. Hashimoto, K. Shimizu, K. Natarajan, Inorg. Chim. Acta, 2005, 358, 2093-2096.

DOI:10.1016/j.ica.2004.12.051

40. N. Raja, R. Ramesh, Spectrochim. Acta Part A. Mol. Biomol. Spectrosc. 2010, 75, 713- 718. DOI:10.1016/j.saa.2009.11.044

41. A. K. Das, S. M. Peng, S. Bhattacharya, J. Chem. Soc., Dalton Trans. 2000, 181-184. DOI:10.1039/a907021d

42. P. Bhattacharyya, M. L. Loza, J. Parr, A. M. Z. Slawin, J. Chem. Soc. Dalton Trans. 1999, 2917-2921.

DOI: $10.1039 / \mathrm{a} 904905 \mathrm{c}$
43. R. Raveendran, S. Pal, Inorg. Chim. Acta 2006, 359, 32123220. DOI:10.1016/j.ica.2006.04.004

44. J. G. Małecki, I. Gryca, Polyhedron 2013, 51, 102-110. DOI:10.1016/j.poly.2012.12.012

45. Z. F. Chen, Z. R. Liao, D. F. Li, W. K. Li, X. G. Meng, J. Inorg. Biochem. 2004, 98, 1315-1318.

DOI:10.1016/j.jinorgbio.2004.04.006

46. S. Sreedaran, K. S. Bharathi, A. K. Rahinan, K. Rajesh, G. Nirmala, V. Narayanan, J. Coord. Chem. 2008, 61, 3594-3609. DOI:10.1080/00958970802087425

47. M. Gonzales-Alvares, G. Alzuet, J. Borras, S. Garcia-Granda, J. M. Montejo-Bernardo, J. Inorg. Biochem. 2003, 96, 443-451. DOI:10.1016/S0162-0134(03)00263-0

48. M. R. Malachowski, J. Carden, M. G. Davidson, W. L. Driessen, J. Reedijk, Inorg. Chim. Acta 1997, 257, 59-67.

DOI:10.1016/S0020-1693(96)05448-5

49. A. L. Abuhijleh, J. Inorg. Biochem. 1994, 55, 255-262. DOI:10.1016/0162-0134(94)85010-0

50. P. S. Subramian, E. Suresh, P. Dastidar. Polyhedron 2004, 23, 2515-2522. DOI:10.1016/j.poly.2004.08.020

51. M. Thirumavalavan, P. Akilan, M. Kandasmary, K. Chinnakali, G. S. Kumar, H. K. Fun, Inorg. Chem. 2003, 42, 3308-3317. DOI:10.1021/ic020633

52. A. Jancso, Z. Paksi, N. Jakab, B. Gyurcsik, A. Rockenbauer, T. Gadja, J. Chem. Soc., Dalton Trans. 2005, 3187-3194. DOI:10.1039/b507655b

53. A. Allam, I. Dechamps-Olivier, J.-B. Behr, R. Plantier-Royon, L. Bopont, Inorg. Chim. Acta 2011, 366, 310-319. DOI:10.1016/j.ica.2010.11.011

54. S. Mistri, H. Puschmann, S. C. Manna, Polyhedron 2016, 115, 155-163. DOI:10.1016/j.poly.2016.05.003

55. M. Das, R. Nasani, M. Saha, S. M. Mobin, S. Mukhopadhyay, Dalton Trans. 2015, 44, 2299-2310. DOI:10.1039/C4DT02675F

56. A. K. Ghosh, M. Mitra, A. Fathima, H. Yadav, A. R. Choudhury, B. U. Nair, R. Ghosh, Polyhedron 2016, 107, 1-18. DOI:10.1016/j.poly.2016.01.015

57. N. Beyazit, B. Çatıkkas,S. Bayraktar, C. Demetgül, J.Mol. Struct. 2016, 1119, 124-132. DOI:10.1016/j.molstruc.2016.04.047

58. A. K. Maji, A. Chatterjee, S. Khan, B. K. Ghosh, R. Ghosh. J. Mol. Struct. 2017, 1146, 821-827.

DOI:10.1016/j.molstruc.2017.06.077

59. S. Mondal, B. Pakhira, A. J. Blake, M. G. B. Drew, S. K. Chattopadhyay, Polyhedron, 2016, 117, 327-337.

DOI:10.1016/j.poly.2016.05.052

60. P. Selvakumar, N. Nanjundan, K. Velmurugan, R. Nandhakuma, R. Narayanasamy, J. Braz. Chem. Soc. 2017, 28, 14141429. DOI:10.21577/0103-5053.20160318

61. S. Anbu, E. C. B. A. Alegria, A. J. L. Pombeiro, Inorg. Chim. Acta 2015, 431, 139-144. DOI:10.1016/j.ica.2014.11.038

62. P. Adak, B. Ghosh, A. Bauzá, A. Frontera, A. J. Blake, M. Corbella, C. D. Mukhopadhyay, S. K. Chattopadhyay, RSC Adv. 2016, 6, 86851-86861. DOI:10.1039/C6RA14059A

63. Y. Thio, X. Yang, J. J. Vittal, Dalton Trans. 2014, 43, 35453556. DOI:10.1039/c3dt52829d

64. S. Majumder, S. Sarkar, S. Sasmal, E. C. Sanudo, S. Mohanta, 
Inorg. Chem. 2011, 50, 7540-7554. DOI:10.1021/ic200409d

65. V. K. Bhardwaj, N. Aliaga-Alcalde, M. Corbella, G. Hundal, Inorg. Chim. Acta 2010, 363, 97-106.

DOI:10.1016/j.ica.2009.09.041

66. (a) A. Szorcsik, F. Matyuska, A. Benyei, N. V. Nagy, R. K. Szilagyi, T. Gajda, Dalton Trans. 2016, 45, 14998-15012.

DOI:10.1039/C6DT01228K

(b) R. E. H. M. B. Osorio, A. Neves, T. P. Camargo, S. L. Mireski, A. J. Bortoluzzi, E. E. Castellano, W. Haase, Z. Tomkowicz, Inorg. Chim. Acta 2015, 435, 153-158.

DOI:10.1016/j.ica.2015.06.023

(c) S. Calancea, S. G. Reis, G. P. Guedes, R. A. A. Cassaro, F. Semaan, F. Lopez-Ortiz, M. G. F. Vaz, Inorg. Chim. Acta 2016, 453, 104-114. DOI:10.1016/j.ica.2016.07.057
67. A. Majumder, S. Goswami, S. R. Batten, M. S. E. Fallah, J. Ribas, S. Mitra, Inorg. Chim. Acta 2006, 359, 2375-2382. DOI:10.1016/j.ica.2006.01.045

68. J. Mukherjee, R. Mukherjee, Inorg. Chim. Acta 2002, 337, 429-438. DOI:10.1016/S0020-1693(02)01106-4

69. (a) M. Das, Z. Afsan, D. Basak, F. Arjmand, D. Ray, Dalton Trans. 2019, 48, 1292-1313. DOI:10.1039/C8DT04183K

(b) K. Ghosh, K. Harms, S. Chattopadhyay, Chemistry Select 2017, 2, 8207-8220. DOI:10.1002/slct.201701536

(c) A. Hazari, L. K. Das, R. M. Kadam, A. Bauzá, A. Frontera, A. Ghosh, Dalton Trans. 2015, 44, 3862-3876. DOI:10.1039/C4DT03446E

(d) S. Das, A. Sahu, M. Joshi, S. Paul, M.Shit, A. R. Choudhury, B. Biswas, Chemistry Select. 2018, 3, 10774-10781. DOI:10.1002/slct.201801084

\section{Povzetek}

$\mathrm{Z}$ uporabo Schiffove baze, pripravljene iz 5-klorosalicilaldehida in $\mathrm{N}, \mathrm{N}$-dimetiletilendiamina kot liganda smo sintetizirali nov rutenijev(III) kompleks z molekulsko formulo $\left[\mathrm{Ru}\left(\mathrm{PPh}_{3}\right) \mathrm{Cl}_{2}(\mathrm{~L})\right]$ (1). Spojino smo karakterizirali $\mathrm{z}$ metodami FTIR, UV-Vis, ciklično voltametrijo in monokristalno rentgensko analizo. Okolica kovinskega iona je nekoliko popačen oktaeder kjer kelatni ligand prispeva donorski niz NNO. Koordinacija okoli rutenija je zaključena $\mathrm{s} \mathrm{PPh}_{3}$ ligandom in dvema kloridnima anionoma, ki skupaj s fenokso kisikom Schiffove baze zagotovijo nevtralnost spojine. Z namenom preučevanja energije povezane $\mathrm{z}$ vezavo halogena smo opravili tudi teoretsko analizo kompleksa, pri čemer smo uporabili MEP in NCI metode. Kompleks 1 kaže aktivnost primerljivo s kateholazo v pretvorbi modelnega substrata 3,5-di-tert-butilkatehola (3,5-DTBC) v ustrezni 3,5-di-tert-butilkinon (3,5-DTBQ) pod aerobnimi pogoji. Parametre encimatske kinetike smo določili iz Lineweaver-Burkovega diagrama $\mathrm{z}$ uporabo Michaelis-Mentenovega modela encimske katalize. Visoka vrednost T.O.N $\left(2.346 \times 10^{3} \mathrm{~h}^{-1}\right)$ kaže na zelo dobro katalitsko delovanje kompleksa 1 pri pretvorbi 3,5-DTBC.

Except when otherwise noted, articles in this journal are published under the terms and conditions of the Creative Commons Attribution 4.0 International License 